\title{
Indonesian Learning Through WhatsApp Group To Create Interactive Learning Conditions
}

\author{
Sugeng Santoso ${ }^{1 *}$, Ni Komang Sarini Dewi ${ }^{2}$ \\ 'Indonesian Language and Literature Education, Ganesha University of Education, Indonesia \\ Udayana Street No.11 Singaraja - Bali, 81116 \\ ${ }^{2}$ English Language Education, Ganesha University of Education, Indonesia \\ Udayana Street No.11 Singaraja - Bali, 81116 \\ "Corresponding author: sugengsantoso@undiksha.ac.id
}

\begin{abstract}
This research aims to use WhatsApp group to Indonesian learning in VIII class students at UPT SMP Negeri 3 Ponggok. This research used qualitative approach because it uses data in the form of words. At the same time, this research used experimental type because it is testing something. The research subjects were from VIII-D class students, and the object was Indonesian learning through WhatsApp group. The data collection techniques were observation, documentation, and questionnaires. Comparative analysis will be processed after the data is obtained. In addition, the analysis was also carried out with Miles and Huberman's technique. Miles and Huberman's technique has several stages; data reduction, data presentation, and drawing conclusions. The research resulted the use of WhatsApp group was more interactive and fun than another method that has been implemented before. Therefore it is increasing student learning outcomes.
\end{abstract}

Keywords: Indonesian, interactive learning, WhatsApp group

\begin{abstract}
Abstrak: Penelitian ini bertujuan untuk mengujicobakan penggunaan grup WhatsApp untuk pembelajaran Bahasa Indonesia kelas VIII UPT SMP Negeri 3 Ponggok. Jenis yang digunakan penelitian kualitatif, karena menggunakan data berbentuk kata-kata. Sedangkan pendekatan penelitian yang digunakan adalah penelitian eksperimen, karena bersifat mengujicobakan sesuatu. Subjek penelitian adalah siswa kelas VIII-D, dan objek yang akan dianalisis adalah pembelajaran Bahasa Indonesia berbasis grup WhatsAapp. Teknik pengumpulan data yang digunakan adalah observasi, dokumentasi, dan kuisioner. Setelah data didapatkan, maka akan diolah analisis perbandingan serta teknik Miles dan Huberman. Teknik Miles dan Huberman memiliki beberapa tahap; reduksi data, penyajian data, serta penarikan kesimpulan. Hasil penelitian yang didapatkan adalah penggunaan grup WhatsApp lebih interaktif dan menyenangkan daripada metode yang sebelumnya sudah diterapkan, sehingga membuat hasil belajar siswa meningkat.
\end{abstract}

Kata Kunci: Bahasa Indonesia, grup WhatsAapp, pembelajaran interaktif

\section{INTRODUCTION}

The virus that originated in Wuhan City, Hubei Province, China, made the world's situation in chaos. In December 2019, the COVID-19 virus began to emerge and eventually spread to various countries. On February 11, 2020, The World Health Organization (WHO) (2020) announced that the name of the virus is Coronavirus Disease (COVID-19), which is caused by the Severe Acute Respiratory Syndrome Coronavirus-2 (SARS-CoV-2) virus. According to The Task Force for Handling COVID-19 Indonesia (2020), the total of COVID-19 virus infections in Indonesia per February 1, 2021, reached 1.089.308 confirmed cases. In addition, 10.994 cases from the previous day, and the number of declared dead cases was 30.277 cases. The Directorate General of Disease Prevention and Control (2020) stated that 
the COVID-19 virus could be transmitted through a splash when an infected patient sneezes or coughs (droplet). Because of this, health protocols are enforced in the form of wearing masks, maintaining distance, and adopting a clean lifestyle. The symptoms of the COVID-19 virus infection include respiratory problems such as fever coughing, sneezing, and shortness of breath. However, based on data from 55,924 cases, the most frequent symptoms were fever, dry cough, shortness of breath, and sore throat (Susilo et al., 2020).

The arrival of the COVID-19 virus in Indonesia has had much impact on essential aspects. This impact is evenly distributed from the health, economy, education, tourism to social sectors. In Indonesia, the real impact is the change of the learning model from face-to-face to online. Hasibuan (in Malyana, 2020) defines online learning as a way of overcoming educational problems regarding learning implementation. The online learning method has an interactive model based on the Internet and Learning Management System (LMS).

The Indonesian government conducts online learning to minimize the spread of the COVID-19 virus. Anugrahana (2020) pointed out, the Minister of Education and Culture of Indonesia, Nadiem Makarim, immediately signed a Circular Number 4 year 2020 concerning the Implementation of Education Policies in an Emergency for the Spread of Coronavirus Disease (COVID-19) on March 24, 2020. The new unplanned system does not mean that the learning process will be better. Many obstacles appear when implementing online learning in Indonesia. First, teachers and students have limited mastery of technology and information. Second, the existing facilities and infrastructure are still insufficient. Third, internet access is still limited in various regions. The last, the lack of readiness about the budget provision in Indonesia (Aji, 2020). Apart from the obstacles mentioned earlier, Santoso (2020) also mentioned that the lack of student motivation, teacher's method is still stagnant, and the learning process has changed into assignments are the obstacles in online learning.

UPT SMP Negeri 3 Ponggok is one of the schools that implements online learning during the pandemic. This school is located in Jatilengger Village, Ponggok District, Blitar Regency. They use Google Classroom to conduct online learning processes. According to Istiamin (2020), the Google Classroom application was chosen as the primary learning application because it has adequate features and an uncomplicated appearance. Apart from using Google Classroom, this school also uses WhatsApp groups as a media to remind students when assignments have been sent.

Furthermore, this school also uses a module as learning media. According to Daryanto (in Mufidah, 2014), a module is a learning material that helps students learn independently (without teachers) and fosters learning motivation. Agustina (in Istiamin, 2020) revealed that the module's function is for an independent student teaching material, a substitute for the role of the teacher, a student learning evaluation tool, and as a student learning reference material.

The Indonesian is one of the compulsory subjects that are taught from primary education to higher education. This is not only motivated by the fact that the Indonesian is the national language but also on the basis of the nature of the Indonesian as an advocate of science. The Center for Development and Empowerment of Educators and Education Personnel (PPPPTK) (2020) stated that Indonesian learning functions as an advocate for science and forms various kinds of thinking structures for students through mastery of various text structures.

Figure 1 is a screenshot about Indonesian learning at UPT SMP Negeri 3 Ponggok, more precisely in VIII-D class with news text material. The learning model applied in these schools is generally the delivery of material and assignments that students must do, without any interaction between students and teachers. Therefore, students will only read the material and do their assignments every day. The impact of learning will make students have less interested and enthusiastic about learning. This can be seen from the number of students who submitted assignments. 


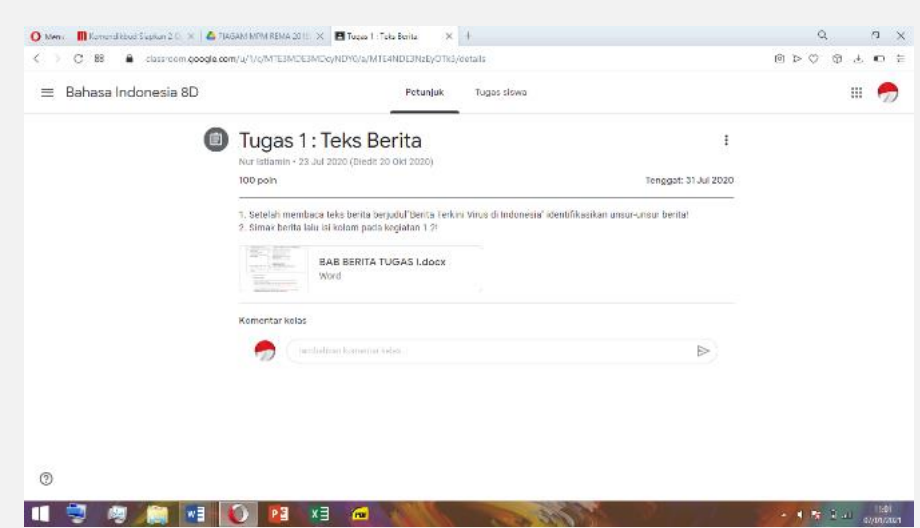

Figure 1. News Text Material Learning in VIII-D Class

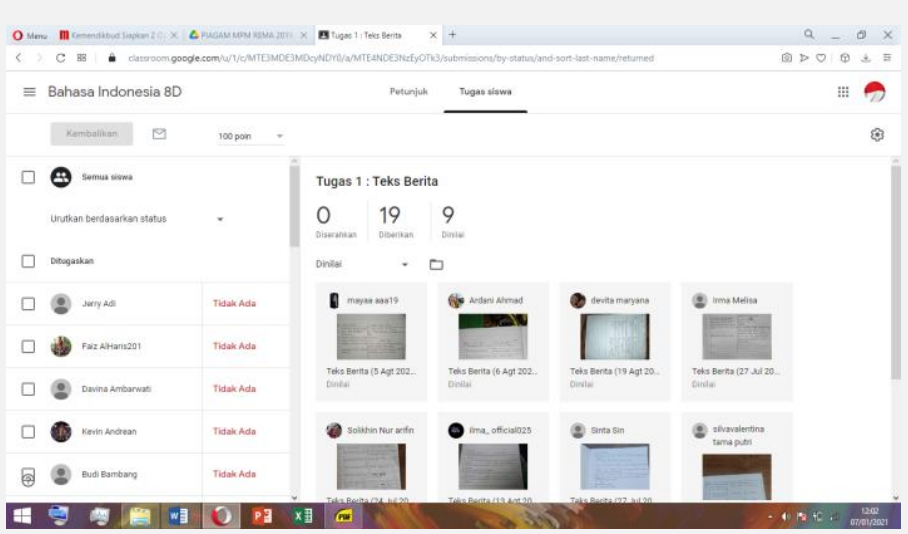

Figure 2. Students that Collected Assignments in VIII-D Class

Based on the Figure 2 above, it can be seen that the number of students who submitted assignments and scored on the news text material through Google Classroom was 9 students. Checking the VIII-D data needs to find out the original number of students who sent assignments and got the score on the material learning, other class data will also be shown for comparison.

Table 1. Recapitulation of News Text Material Learning Results

\begin{tabular}{lll}
\hline Information & VIII-C Class & VIII-D Class \\
\hline $\begin{array}{l}\text { Students submitted the } \\
\text { assignments in Google Classroom }\end{array}$ & 7 & 9 \\
\hline $\begin{array}{l}\text { Students submitted the } \\
\text { assignments, not through Google } \\
\text { Classroom }\end{array}$ & 3 & 5 \\
\hline $\begin{array}{l}\text { Students do not submit the } \\
\text { assignments }\end{array}$ & 22 & 18 \\
\hline Total & 32 & 32 \\
\hline $\begin{array}{l}\text { Source: Score Data of Eight-grade Student } \\
\end{array}$
\end{tabular}

VIII-D class students have low participation, considering that $50 \%$ of students did not submit their assignments at all. However, students' participation in VIII-D class was even lower, because the number of students who did not submitted assignments was $64,3 \%$. Meanwhile, 
the teacher only could give the students' score through the submission in online assignments that have submitted by students since there is no offline interaction between teacher and students at the class,

Istiamin (2020) has researched using modules in online learning in VIII-C and VIII-D class at UPT SMP Negeri 3 Ponggok. It resulted 17,2\% of the students agreed that the use of Indonesian language learning modules in online learning made it easy for them to understand the materials. It was $15,5 \%$ of students chose "maybe", and $67,2 \%$ of students chose "disagree". In addition, 8,6\% of the students stated "agree" about using Indonesian language learning modules in online learning makes learning more interesting. About $12 \%$ of students chose "maybe", and 79,3\% of students chose "disagree".

From some of the explanations above, this research will conduct experiments to create interactive and fun learning for students using WhatsApp. Afnibar \& N (2020) state that WhatsApp is a free communication platform installed on a smartphone. The use of internet connection on WhatsApp makes it possible to send text messages, pictures, and videos to users. However, unfortunately, these facilities are sometimes underutilized in online learning. Sahidillah \& Miftahurrisqi, (2019) reveal that WhatsApp is often not used as a medium for students' literacy and learning. The experiment will be held by using the WhatsApp group. This experiment will test the use of WhatsApp groups as an Indonesian learning application.

\section{METHOD}

This research used a qualitative research approach. A qualitative approach produces data in written or spoken words (Siyoto \& Sodik, 2016). The type of research used experimental research. According to Jaedun (2011), experimental research is carried out deliberately by researchers by giving special treatment to the subject to evoke a situation/event, which will be examined due to the treatment. The experiment was an intact-group comparison, which means experimenting by dividing the subjects into two groups: the experimental and control classes.

The subjects in this research were VIII-C class and VIII-D class students at UPT SMP Negeri 3 Ponggok. VIII-D class will be used as an experimental class, and VIII-C class will be used as a control class. The object of this research is to test the use of WhatsApp as an Indonesian learning application. The material to be used in experimental learning is about exposition text, in accordance with the applicable syllabus.

Table 2. Subjects Total

\begin{tabular}{lll}
\hline Class & Information & Number \\
\hline VIII-C & Control Class & 32 \\
\hline VIII-D & Experimental Class & 32 \\
\hline Total & & 64 \\
\hline
\end{tabular}

This research was held on 12 to 22 October, 2020. The passed stages were learning design, making learning media, teaching and learning activities, and assessment. This research was conducted entirely online, in accordance with the COVID-19 pandemic health protocol. The data collection methods used in this research were observation, documentation, and questionnaires. Observation is used to observe Indonesian learning previously carried out in VIII-C and VIII-D class. The observations were made online. The document reviewed in this study is the Indonesian score data for VIII-C class and VIII-D class students. The questionnaire was conducted to obtain data in the form of students' answers regarding the responses to the Indonesian learning based on WhatsApp group.

The data analysis technique used comparative analysis (comparison) of learning outcomes in the experimental class (VIII-C) and the control class (VIII-D). The results of the analyzed data will be presented in descriptive form. Furthermore, the Miles and Huberman model analysis was carried out to analyze the questionnaire data. Santoso et al., (2018) stated 
that the Miles and Huberman model has three components, namely data reduction, data presentation, and drawing conclusions. Data reduction is the activity of sorting out the main things in the data relevant to research. Reduction is made by eliminating unnecessary parts of the data. Data presentation is an effort to display information that has been systematically compiled. Drawing conclusions is the formulation of conclusions based on data obtained.

In obtaining data, research instruments are needed. Research instruments are tools used by researchers in gathering information (data) in research (Nasution, 2016). The research instrument used in this study was a questionnaire guide. The questions used in the questionnaire are formulated by analyzing and considering the experiments that have been carried out. The questionnaire questions that have been obtained are as follows.

1) Does Indonesian learning through WhatsApp group make the material easy to understand?

2) Does Indonesian learning through WhatsApp group make learning fun?

3) Does Indonesian learning through WhatsApp group make learning more interesting?

4) Does Indonesian learning through WhatsApp group is easier to implement than the previous learning model?

5) Does Indonesian learning through WhatsApp group is enough to carry out learning?

6) Is it recommended that Indonesian learning through WhatsApp group to be continued?

The response options that are available and can be chosen by students are "agree", "maybe", and "disagree". The three answer options have been carefully formulated and considered based on literature studies and previous similar studies.

\section{RESULT AND DISCUSSION}

\section{The Learning Design of Indonesian Learning through WhatsApp Group}

Before conducting the learning process, several things need to be prepared to make the experiment run smoothly, such as the concept of learning, time allocation, the material chosen, and learning media. Specifically, the design of Indonesian learning through WhatsApp group tested in this research can be seen as follows.

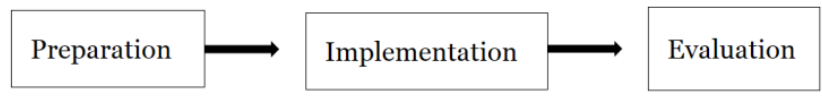

Figure 3. Learning Design

The preparation stage is held by asking permission from the school target, formulating learning concepts, formulating time allocations, selecting learning material, making learning media, and determining the day for the experiment will be implemented. From the observations, it is agreed that the experiment will be held on Thursday, October 15, 2020. The material to be taught is the shapes of exposition text development. The learning media used is a slide (PowerPoint) which has been designed as attractive as possible and converted into pdf format. The concept applied in this learning is the same as the learning concept in general, namely starting with the opening, giving material, question-and-answer, and giving assignments.

The second stage is the implementation. Implementation is the most important stage in this research because the learning process will be held using WhatsApp group that is arranged like a classroom environment. Therefore, it will become more interactive. Then, the last stage is evaluation. The evaluation stage is carried out by looking at the shortcomings and constraints of the learning experiment. In addition, this evaluation stage is also used to assess the assignments that students have submitted. 


\section{Implementation of Indonesian Language Learning through WhatsApp Group}

Indonesian learning through WhatsApp group has conducted well. Students' participation is also quite high compared to the previously applied learning model. In this learning model, students are stimulated to remember the previous material, the material has a more attractive appearance, and the students are invited to ask questions. Those steps of teaching were not present in the previous learning model.

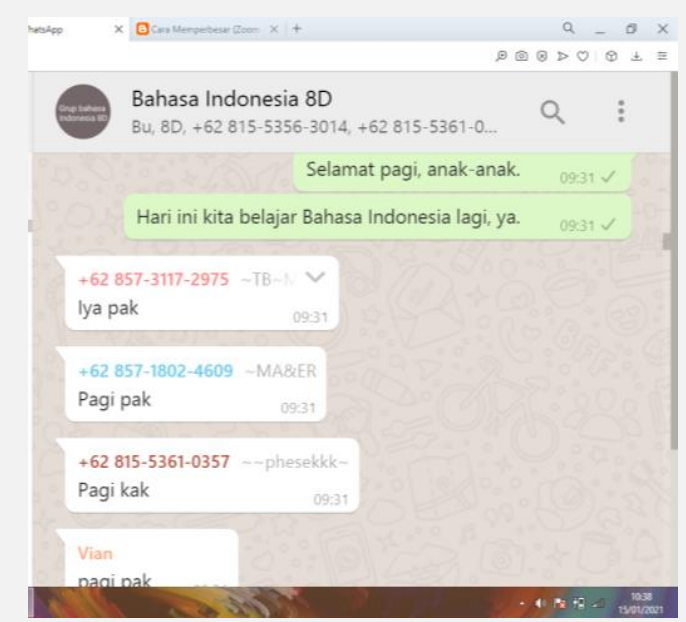

Figure 4. Opening

First, the opening section is important to do by the teacher. In this experiment, the opening was done by greeting the students. This is done to strengthen the interaction between students and teachers. The teacher can also use other variations in increasing interaction with students, such as asking students how they are or asking students about their breakfast menus.

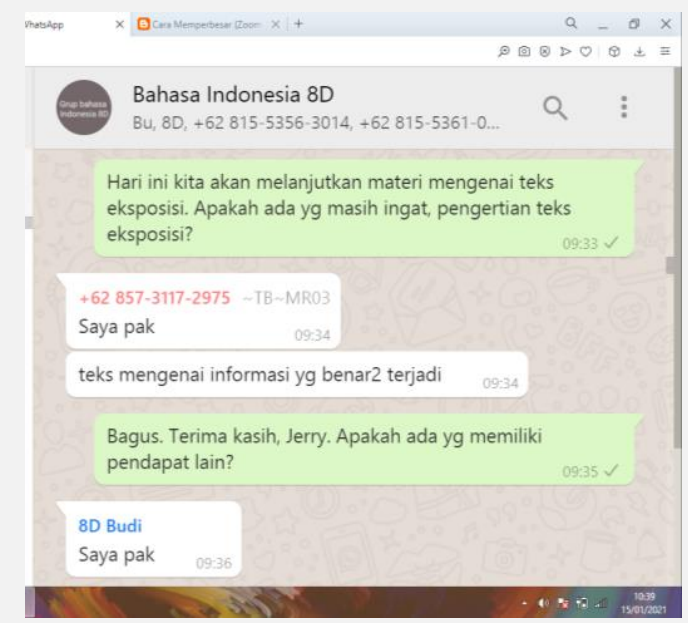

Figure 5. Reviewing Previous Learning

Reviewing previous learning aims to stimulate student memory. It also serves to inform students about the relevance of learning indirectly. In this stage, several students offer themselves to answer questions. 


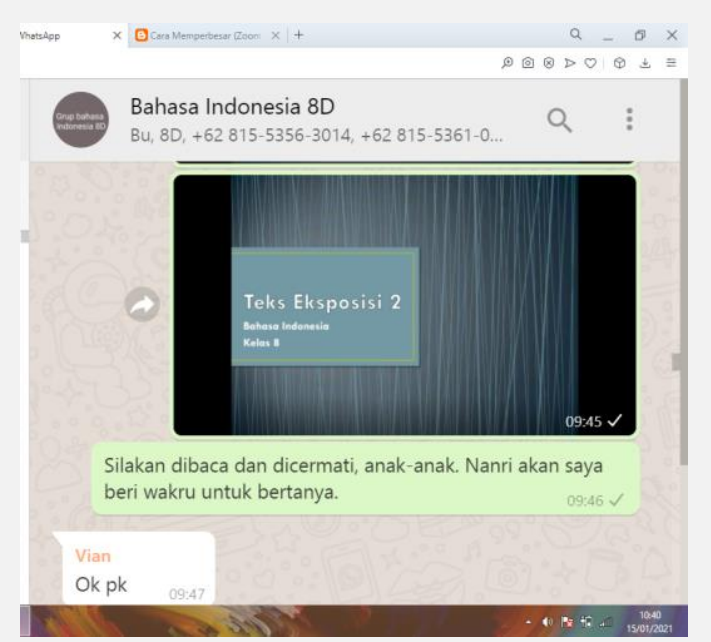

Figure 6. Learning Material Giving

Next, the teacher sent the material that has learnt on this day. The material is about the shapes of developing the exposition text. The material is presented in slide creations (PowerPoint), converted into pdf format to make it more interesting. In this learning, the teacher provided a link containing learning material for students. Hence, they have more references to learn. Students are given about 15 minutes to read and understand the material by themselves.

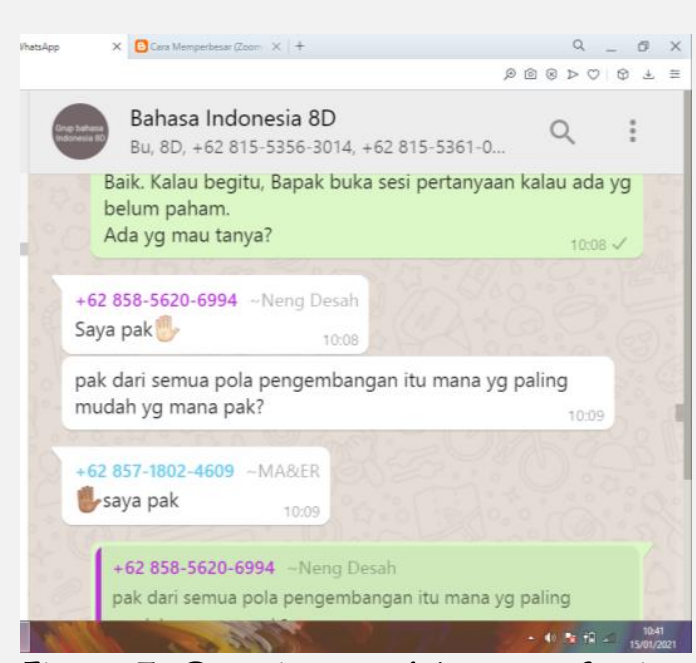

Figure 7. Questions and Answers Session

The question and answer section is the next activity after reading the material. At this stage, the teacher's role was to confirm the questions that arise from students regarding the material that is studied. In the question and answer activity, several students in D class asked questions about things that they did not understand. This activity shows students' enthusiasm rather than the previous learning model. 


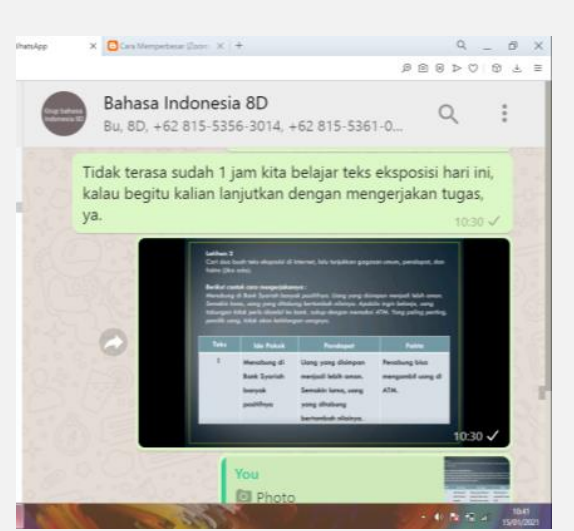

Figure 8. Assignment

Indonesian language learning through WhatsApp group activities ended with giving assignments and closing. Giving assignments are implemented to test the understanding obtained by students after the learning. Assignments can be submitted via Google Classroom or via private message to the teacher. The time given to do the assignment is 3 days. This allowance is enforced considering that not all students have sufficient internet package.

\section{Indonesian Learning through WhatsApp Group Results}

After the learning is carried out and the time for collecting the assignments is over, the student's score data is processed. This section describes student of VIII-C class's (control class) and VIII-D class's students (experimental class) learning outcomes. Gagne (in Labinta, 2014) argues, there are three types of learning outcomes, namely affective, cognitive, and psychomotor. Then, Risda (in Labinta, 2014), defines that learning outcomes are results achieved or obtained by students in a subject obtained through certain tests. The following is data on student learning outcomes obtained from Indonesian learning based on the WhatsApp group.

Table 3. Student Participation

\begin{tabular}{lll}
\hline Information & VIII-C & VIII-D \\
\hline $\begin{array}{l}\text { Students that } \\
\text { Submitted Assignments }\end{array}$ & 7 & 28 \\
\hline $\begin{array}{l}\text { Students Did Not } \\
\text { Submitted Assignments }\end{array}$ & 25 & 4 \\
\hline Total & 32 & 32 \\
\hline
\end{tabular}

From the data above, it can be seen that the number of students in VIII-C who collected assignments was 7 students or $27.9 \%$ of the total students. The number of students in VIII-C class who did not submit assignments was 25 students or $78.1 \%$ of the total students. This is inversely proportional to student participation in the experimental class. In VIII-D class, the number of students who submitted assignments was 28 students or $87.5 \%$ of the total students. Meanwhile, the number of students who did not collect was 4 students or $12.5 \%$ of the total students. From this statement, it can be said that the participation of the experimental class students was higher than the control class students.

Table 4. Range of Scores

\begin{tabular}{|c|c|c|c|c|}
\hline Class & $>75$ Score & 75 - 79 Score & 80 - 89 Score & $\leq 90$ Score \\
\hline VIII-C & 1 & 1 & 3 & 2 \\
\hline VIII-D & 0 & 15 & 11 & 2 \\
\hline
\end{tabular}


The range scores obtained by students is grouped into four parts. The groups are scores below 75 , the score range is 75 to 79 , the score ranges from 80 to 89 , and scores greater than equal to 90 . Based on the table above, it can be seen that the number of students who scored below 75 for VIII-C class was 1 student, and for VIII-D class there was none. The number of students who scored 75 to 79 in VIII-C class was 1 student, while in VIII-D class were 15 students. The number of students who scored 80 to 89 inVIII-C class was 3 students, while there were 11 students in VIII-D class. The number of students who scored more than equal to 90 in VIII-C class was 2 students, and in VIII-D class there were 2 as well. Thus, it can be said that the majority of the experimental class students scored 75 to 79 , while the majority of control class students scored 80 to 89.

Table 5. Average Score

\begin{tabular}{llll}
\hline Class & Lowest Score & Highest Score & Average \\
\hline VIII-C & 0 & 90 & 71,1 \\
\hline VIII-D & 75 & 95 & 78,7 \\
\hline
\end{tabular}

From the scores that have been obtained, the average score of the experimental class students and control class students are as shown in the table above. The score above are written based on students who have submitted assignments, either via Google Classroom or via private messages. In VIII-C class, the lowest score obtained was 0 . This happened because there was a student who sent an empty assignment, so it was not graded. The highest score in VIII-C class was 90 , and the average score of students submitting assignments was 71,1 . For VIII-D class, the lowest score obtained by students was 75 , the highest score obtained by students was 95, and the average score of students who submitted assignments was 78,7.

Thus, it can be said that the scores obtained by the experimental class students (VIII-D class) are better than the control class students (VIII-C class). At lowest score, students of VIII-D class are better than VIII-C class. At the highest score, VIII-D class students are also better than VIII-C class and the different points is 5 points. Meanwhile, on average, VIII-D class students are better than VIII-C class by a difference of 7,6.

\section{Student's Perceptions of Indonesian Language Learning through WhatsApp Group}

Student's perceptions about the Indonesian learning through WhatsApp group were obtained through a questionnaire that all objects had filled. After the data is processed, several descriptions are found as follows.

First, $87,5 \%$ of the experimental class students chose "agree" that Indonesian language learning through WhatsApp group made the material easy to understand. Meanwhile, 9,38\% of the experimental class students chose "disagree" and 3,12\% chose "maybe". Thus, it can be defined that experimental class students felt that Indonesian learning language through WhatsApp group makes the material easy to understand.

Second, $93,75 \%$ of the experimental class students chose "agree" that Indonesian learning through WhatsApp group made learning fun. Meanwhile, 6,25\% of the experimental class students chose "disagree" and none of the students chose the "maybe". Thus, it can be defined that experimental class students felt that Indonesian learning through WhatsApp group makes learning fun.

Third, 93.75\% of the experimental class students chose "agree" that Indonesian learning through WhatsApp group made learning more interesting. Meanwhile, $6.25 \%$ of students in the experimental class chose "disagree" and none student chose the answer "maybe". This amount is the same as the previous questionnaire questions. Thus, it can be defined that students in the experimental class felt that Indonesian learning through WhatsApp group makes learning more interesting. 
Fourth, $84.38 \%$ of students in the experimental class chose "agree" that Indonesian learning through WhatsApp group is easier to implement than the previous learning model. Meanwhile, $12.5 \%$ of the experimental class students chose "disagree" and $6.25 \%$ chose "maybe". Thus, it can be defined that experimental class students felt that Indonesian learning through WhatsApp group is easier to implement than the previous model learning.

Next, $96.88 \%$ of the experimental class students chose "agree" that Indonesian learning through WhatsApp group was enough to carry out in the learning process. Meanwhile, 3,12\% of students in the experimental class chose "disagree" and 3,12\% chose "maybe". Thus, it can be defined that students in the experimental class felt Indonesian language through WhatsApp group is enough to carry out in learning process.

The last, $93,75 \%$ of the experimental class students chose "agree" that the Indonesian learning through WhatsApp group is recommended to continue to be applied. 6,25\% of students in the experimental class chose "disagree" and none students chose "maybe". Thus, it can be defined that experimental class students felt Indonesian learning through WhatsApp group is recommended to continue to be applied.

\section{CONCLUSION}

After the experiment was carried out, students of VIII-D class had better results than VIII$C$ class, who still used Google Classroom only. It can be seen by the number of students who collected their assignments which is VIII-D class has more participation than $C$ class. While the average score of $D$ class is also better than VIII-C class. The questionnaire found that many students in VIII-D class agreed if Indonesian Language learning through WhatsApp group made the material easy to understand, made learning more fun, and recommended to be applied continually. Apart from being interactive, this learning model also offers other advantages, such as saving more internet package. Students who have mobile phones with middle to lower features can also take this learning.

\section{ACKNOWLEDGMENTS}

A big thank you to reviewers, editors, and all managers of The Journal of Digital Learning and Education, MO.RI Publishing for providing the opportunity to the authors to publish this journal. The authors also want to thank the UPT SMP Negeri 3 Ponggok for being willing to be used as a trial location. Lastly, the authors would like to thank the alma mater, Ganesha University of Education.

\section{REFERENCES}

Aji, R. H. S. (2020). Dampak Covid-19 pada Bidang Pendidikan di Indonesia: Sekolah, Keterampilan, dan Proses Belajar. Jurnal Sosial Dan Budaya Syar-i FSH UIN Syarf Hidayatullah Jakarta, 7(5). https://doi.org/10.15408/sjsbs.v7i5.15314

Anugrahana, A. (2020). Hambatan, Solusi dan Harapan: Pembelajaran Daring Selama Masa Pandemi Covid-19 Oleh Guru Sekolah Dasar. Scholaria: Jurnal Pendidikan Dan Kebudayaan, 10(3). https://doi.org/10.24246/j.js.2020.v10.i3.p282-289

Istiamin, N. (2020). Penggunaan Modul Pembelajaran Bahasa Indonesia pada Siswa Kelas VIII UPT SMP Negeri 3 Ponggok. Dharmas Education Journal, 1(2).

Jaedun, A. (2011). Metodologi Penelitian Eksperimen. Pelatihan Penulisan Artikel Ilmiah, LPMP Provinsi Daerah Istimewa Yogyakarta.

Labinta, Y. (2014). Upaya Meningkatkan Hasil Belajar Siswa melalui Penggunaan Media Cetak Sebagai Sumber Belajar IPS di Kelas IV SDN Unsongi Kec. Bungku Timur Kabupaten Morowali. Jurnal Kreatif Tadulako Online, 3(1). 
Malyana, A. (2020). Pelaksanaan Pembelajaran Daring dan Luring dengan Metode Bimbingan Berkelanjutan pada Guru Sekolah Dasar di Teluk Betung Utara Bandar Lampung. Pedagogia : Jurnal Ilmiah Pendidikan Dasar Indonesia, 2(1).

Mufidah, C. I. (2014). Pengembangan Modul Pembelajaran Pada Kompetensi Dasar Hubungan Masyarakat Kelas X APK 2 di SMKN 10 Surabaya. Jurnal Administrasi Perkantoran, 2(2).

Nasution, H. F. (2016). Instrumen Penelitian dan Urgensinya dalam Penelitian Kuantitaif. Padangsidimpuan: Fakultas Ekonomi dan Bisnis Islam IAIN Padangsidimpuan.

Sahidillah, M. W., \& Miftahurrisqi, P. (2019). WhatsApp sebagai Media Literasi Digital Siswa. Jurnal Varia Pendidikan, 3(1).

Santoso, S. (2020). Kegiatan Belajar Bersama Angkring Sinau Sebagai solusi Pengondisian Belajar Aktif dan Kreatif di Tengah Pandemi Covid-19. Civics Education and Social Sciense Journal (CESSJ), 2(2).

Santoso, S., Hidayat, P., \& Widyastini, N. W. (2018). Penerapan Tri Hita Karana untuk Membentuk Karakter Siswa Taman Kanak-kanak dalam Menuju Indonesia Emas 2045. Paper. Singaraja: Universitas Pendidikan Ganesha.

Siyoto, S., \& Sodik, M. A. (2016). Dasar Metodologi Penelitian. Yogyakarta: Literasi Media Publishing.

Susilo, A., Rumende, C. M., Pitoyo, C. W., Santoso, W. D., Yulianti, M., Herikurniawan, H., Sinto, R., Singh, G., Nainggolan, L., Nelwan, E. J., Chen, L. K., Widhani, A., Wijaya, E., Wicaksana, B., Maksum, M., Annisa, F., Jasirwan, C. O. M., \& Yunihastuti, E. (2020). Coronavirus Disease 2019: Tinjauan Literatur Terkini. Jurnal Penyakit Dalam Indonesia, 7(1). https://doi.org/10.7454/jpdi.v7i1.415

The Center for Development and Empowerment of Educators and Education Personnel (PPPPTK). (2020). Diklat Model Pembelajaran Berbasis Teks Mata Pelajaran Bahasa Indonesia SMP, SMA dan SMK. Retrieved January, 5th 2021, from http://p4tkbahasa.kemdikbud.go.id/2019/04/05/diklat-model-pembelajaran-berbasisteks-mata-pelajaran-bahasa-indonesia-smp-sma-smk/.

The Directorate General of Disease Prevention and Control. (2020). Kesiapan Kemenkes dalam Menghadapi Outbreak Novel Coronavirus (2019-nCoV). Simposium PAPDI Forum, 29 Januari 2020.

The Task Force for Handling COVID-19 Indonesia. (2020). Peta Persebaran. Retrieved February, 1st 2021, from https://covid19.go.id/peta-sebaran.

The World Health Organization (WHO). (2020). Naming The Coronavirus Disease (COVID19) and The Virus that Causes It. Retrieved February, 1st 2021, from https://www.who.int/emergencies/diseases/novel-coronavirus-2019/technicalguidance/naming-the-coronavirus-disease-(covid-2019)-and-the-virus-that-causes-it. 